\title{
Diploid Potato Hybrids as Sources of Resistance to Blackspot Bruising
}

\author{
Agnieszka Hara-Skrzypiec • Henryka Jakuczun
}

Published online: 10 May 2013

(C) The Author(s) 2013. This article is published with open access at Springerlink.com

\begin{abstract}
Resistance to bruising is an important quality trait of potato depending on multiple genetic and environmental factors. Thirty one interspecific diploid hybrids and two tetraploid standards were evaluated for resistance to bruising in 2 years. Diploids originated from crosses between wild and primitive Solanum species and dihaploids of $S$. tuberosum. Two-year mean values of bruising resistance of tested genotypes indicated significant variability of the trait. Analysis of variance showed significant effects of genotype, year and interaction between them on the trait. Broad-sense heritability of bruising resistance was estimated as moderately high, $\mathrm{Hb}=0.73$. Content of L-tyrosine, the main substrate of discoloration reaction, was not significantly correlated with brusing in tested diploid hybrids. The clones, that were resistant to blackspot bruise, also combined quality traits and resistances to many pathogens. All these traits could be transferred together into tetraploid level in $4 \mathrm{x} \times 2 \mathrm{x}$ crosses via male $2 \mathrm{n}$ gametes produced by diploid hybrids.
\end{abstract}

Resumen La Resistencia al daño mecánico es un carácter importante en la calidad de la papa que depende de múltiples factores genéticos y del ambiente. Se evaluaron 31 híbridos diploides interespecíficos y dos estándares tetraploides para resistencia a la magulladura en dos años. Los diploides se originaron de las cruzas entre especies silvestres y primitivas de Solanum y dihaploides de $S$. tuberosum. Los valores de las medias de dos años de resistencia al daño de los genotipos probados indicaron variabilidad significativa del carácter. El análisis de varianza mostró efectos significativos de genotipo, año e interacción entre ellos en el carácter. Heredabilidad, en un amplio

A. Hara-Skrzypiec $(\bowtie) \cdot H$. Jakuczun

Plant Breeding and Acclimatization Institute - National Research

Center (IHAR-PIB), Młochów Research Center, Platanowa 19,

05-831 Młochów, Poland

e-mail: a.hara@ihar.edu.pl sentido de resistencia al daño mecánico, se estimó como moderadamente alta, $\mathrm{Hb}=0.73$. El contenido de L-tirosina, el principal sustrato de la reacción de oscurecimiento no estuvo correlacionado significativamente con el daño en los híbridos diploides probados. Los clones, que fueron resistentes a la mancha oscura, también combinaron los caracteres de calidad y resistencia a muchos patógenos. Todos estos caracteres pudieron transferirse juntos a nivel tetraploide en cruzas $4 \mathrm{x} \times 2 \mathrm{x}$ vía gametos macho $2 \mathrm{n}$ producidos en híbridos diploides.

Keywords Internal discolorations $\cdot \mathrm{L}$ tyrosine $\cdot$ Interspecific diploid Solanum hybrids

\begin{tabular}{|c|c|}
\hline \multicolumn{2}{|c|}{ Abbreviations } \\
\hline IHAR & $\begin{array}{l}\text { PIB Plant Breeding and Acclimatization Institute - } \\
\text { National Research Center }\end{array}$ \\
\hline HPLC & High Performance Liquid Chromatography \\
\hline $\mathrm{RP}$ & $\begin{array}{l}\text { HPLC Reverse Phase High Performance Liquid } \\
\text { Chromatography }\end{array}$ \\
\hline $\mathrm{PPO}$ & Polyphenol Oxidase \\
\hline PLRV & Potato Leafroll Virus \\
\hline PVX & Potato Virus X \\
\hline PVY & Potato Virus Y \\
\hline PVM & Potato Virus M \\
\hline
\end{tabular}

\section{Introduction}

Blackspot bruising is an undesired formation of discolorations under the potato tuber skin initiated by mechanical impact. When cells are damaged, polyphenol oxidase (PPO) and phenols, normally separated by cellular compartmentation, come into contact. A series of oxidative reactions of phenols, primarily tyrosine, result in the formation of melanins (Cobb 1999). According to studies $42 \%$ of internal 
bruising is formed after harvesting, and that value increases to $54 \%$ after grading (Peters 1996). Internal discolorations drastically reduce commercial value of tubers, lead to rejection of the crop by consumers and processing industry and considerable economic losses (Storey 2007).

Blackspot bruising is a complex trait and depends on multiple factors: genotype, environment, anatomical, physical and physiological properties of tuber tissues such as starch content (Zgórska 2000; Urbany et al. 2011), tuber age, turgor pressure (Lærke et al. 2000, 2002a). According to many authors, blackspot bruise resistance depends essentially on the genetic factors which was indicated by the large share of this component in the analysis of variance (Zgórska 2000; Komorowska-Jędrys et al. 2002; Domkářová and Vokál 2005; Domański et al. 2007). Pavek et al. (1993) have showed very high heritability in narrow sense $\left(\mathrm{H}_{\mathrm{n}}=0.85\right)$ of blackspot bruise susceptibility. Results of KomorowskaJędrys et al. (2002), Domański et al. (2007) and Urbany et al. (2011) studies have indicated mid- high to high heritability in broad sense.

The utilization of wild potato species could be potential approach in prevention of bruising in the breeding programs. So far, one of wild species, Solanum hjertingii, has been identified as potential source of resistance to blackening (Woodwards and Jackson 1985). S. hjertingii has been an object of studies on PPO role in discoloration formation by several authors (Sim et al. 1997; Brown et al. 1999; Culley et al. 2002).

The level of tyrosine content and activity of PPO are considered to be the main factors involved in blackspot bruise formation (McGarry et al. 1996). The importance of PPO in discoloration process was confirmed by results in many studies (Coetzer et al. 2001; Arican and Gozukirmizi 2003; Urbany et al. 2011, 2012). Tyrosine is an essential substrate for discoloration reaction. The results of some earlier studies have indicated that tyrosine level is well correlated with enzymatic discoloration potential after tissue homogenization and after abrasive peeling (Dean et al. 1993). On the other hand, no correlation between bruising and tyrosine level has been found in studies using impact method (Mondy and Munshi 1993; Stevens and Davelaar 1997; Strehmel et al. 2010). Mondy and Munshi (1993) studied two potato cultivars, one resistant and one susceptible to bruising, have found that tyrosine level was not a limiting factor for bruising determination, since in the susceptible cultivar they observed a lower level of tyrosine. Stevens and Davelaar (1997) have demonstrated positive correlation between potential to discoloration formation and tyrosine content, but at the same time they have not found correlation between blackspot bruise susceptibility and level of tyrosine. Strehmel and coworkers (2010) have proved that the level of tyrosine did not change significantly after mechanical impact in two tested cultivars. Before impact, the content of tyrosine was higher in the cultivar resistant to blackspot bruise. Other potential monophenolic substrates present in tubers, like caffeic and chlorogenic acid were not correlated with the blackspot formation (Laerke et al. 2002b).

Until now complex diploid Solanum hybrids obtained in IHAR-PIB Młochów, broadly tested and used for many purposes, were not evaluated for blackspot bruise resistance. They originated from a long- term program aimed at improving resistances to pathogens and quality traits by exploitation of new variation present in wild and primitively cultivated Solanum species (Zimnoch-Guzowska et al. 1998). The goal of the present study was to define variation in susceptibility to blackspot bruising among interspecific diploid hybrids. We would like to demonstrate usefulness of selected Solanum hybrids in potato breeding as sources of high resistance to blackspot bruise.

\section{Material and Methods}

\section{Plant Material}

From crosses between interspecific hybrids, 31 diploid clones were selected for this study (Table 1). They were resulted from long-term recombinant breeding process. In their pedigree there are following Solanum species: Solanum acaule, $S$. chacoense, $S$. demissum, S. goniocalyx, $S$. gourlayi, S. microdontum, S. phureja, S. stenotomum, S. verrucosum, S. yungasense and dihaploids of S. tuberosum. A detailed composition of the material is shown in Table 1. Resistances to PLRV, PVX, PVY, PVM, Synchytrium endobioticum, Phytophthora infestans and Pectobacterium carotovorum spp. carotovorum were identified in these clones along selection process (Table 2). Diploid clones, used in the experiment, possessed different leading traits: table usefulness, usefulness for chip processing, high starch content, resistance to soft rot and resistance to late blight. Non- bruising table cultivar (cv.) Vitara and bruising starch cv. Hinga were used as positive and negative standards.

\section{Growing and Storage Conditions}

All tested diploid clones and cultivars were planted in the end of April and harvested in the end of September in 2008 and 2009. They were propagated in experimental fields of IHAR-PIB Młochów. They were fertilized with 90, 90, $170 \mathrm{~kg} \mathrm{~h}^{-1}$ of N, P and $\mathrm{K}$ in 2008 and $120,90,180 \mathrm{~kg} \mathrm{~h}^{-1}$ of $\mathrm{N}, \mathrm{P}$ and $\mathrm{K}$ in 2009 , treated with pesticide whenever necessary. The total amounts of rainfall during the entire growing period were $187.7 \mathrm{~mm}$ and $348.2 \mathrm{~mm}$ in 2008 and 2009 , respectively. The average daily temperatures during 5 months of growing season (from May to September) were similar in both years, $13.5^{\circ} \mathrm{C}, 18.7^{\circ} \mathrm{C}, 19.2{ }^{\circ} \mathrm{C}, 19.0^{\circ} \mathrm{C}$, 
Table 1 Pedigree of tested diploid interspecific hybrids. Diploid clones are ordered according to increasing susceptibility to bruising

\begin{tabular}{|c|c|c|c|c|c|c|c|c|c|c|c|c|c|}
\hline \multirow[t]{2}{*}{ Clone } & \multirow[t]{2}{*}{ Parental forms } & \multirow{2}{*}{$\begin{array}{l}\text { Mean surface of } \\
\text { blackspot bruises } \\
\text { (scale } 1-9 \text { ) }\end{array}$} & \multicolumn{11}{|c|}{ Theoretical contribution of Solanum species in \% } \\
\hline & & & $t b r$ & acl & chc & $d m s$ & $g r l$ & $m c d$ & phu & ver & yun & stn-phu & gon \\
\hline DG 03-170 & DG $97-266 \times$ DG $97-1805$ & 9.0 & 71.8 & 0.6 & 5.0 & 0.6 & 1.2 & 0.8 & 16.4 & 1.6 & 2.0 & & \\
\hline DG 03-232 & DG 92-4862×CE-C 69 & 9.0 & 71.0 & 0.8 & 4.6 & 0.8 & 1.5 & 0.8 & 16.5 & 1.6 & 2.4 & & \\
\hline DG 03-460 & DG 97-1805×DG97-1506 & 9.0 & 68.6 & 1.0 & 5.0 & 1.0 & 3.9 & 0.8 & 13.6 & 1.6 & 3.0 & 1.5 & \\
\hline DG 97-1805 & DG $97-1 \times$ DG $97-1805$ & 9.0 & 70.8 & 0.8 & 6.8 & 0.8 & 2.4 & 1.2 & 11.8 & 2.4 & 3.0 & & \\
\hline DG 03-131 & DG $97-264 \times$ DG $97-1805$ & 8.8 & 72.1 & 0.8 & 8.4 & 0.8 & 2.0 & 0.8 & 10.7 & 1.6 & 2.8 & & \\
\hline DG $03-226$ & DG $97-1805 \times$ DG97-1506 & 8.7 & 68.6 & 1.0 & 5.0 & 1.0 & 3.9 & 0.8 & 13.6 & 1.6 & 3.0 & 1.5 & \\
\hline DW 96-667 & DG $88-214 \times$ DW 92-3089 & 8.6 & 61.6 & 1.2 & 19.9 & 1.2 & 6.9 & 3.2 & 1.2 & 3.2 & 1.6 & & \\
\hline DG 03-124 & DG $97-264 \times$ DG $97-1506$ & 8.5 & 70.3 & 1.0 & 9.7 & 0.8 & 4.3 & 0.8 & 7.4 & 1.6 & 2.6 & 1.5 & \\
\hline DW 96-1025 & DW 92-2337×DW 87-4204 & 8.3 & 49.3 & & 23.0 & & 3.1 & 1.6 & 18.7 & & 2.7 & & \\
\hline DG 00-481 & DW 92-2337×DW 87-4204 & 8.3 & 74.1 & 1.0 & 8.9 & 1.0 & 7.8 & & 7.2 & & & & \\
\hline DG 03-150 & DG $97-264 \times$ DG $97-1805$ & 8.2 & 72.1 & 0.8 & 8.4 & 0.8 & 2.0 & 0.8 & 10.7 & 1.6 & 2.8 & & \\
\hline DG 97-943 & DG 93-352×DG 92-227 & 7.8 & 72.7 & 0.4 & 8.6 & 0.4 & 4.6 & & 6.6 & & 3.6 & 3.1 & \\
\hline DG01-144 & DG 91-28×DG 91-234 & 7.4 & 54.5 & 0.8 & 7.8 & 0.8 & 1.5 & 1.6 & 25.8 & 3.2 & 4.0 & & \\
\hline DG 01-290 & DG 92-227×DG 94-668 & 7.0 & 61.0 & 0.4 & 16.8 & 0.4 & 4.6 & 1.6 & 6.6 & 1.6 & 3.9 & 3.1 & \\
\hline DG 06-1072 & DW $96-1025 \times$ DG 00-525 & 6.9 & 65.2 & 1.2 & 17.8 & 1.2 & 6.6 & 1.2 & 4.3 & 1.2 & 1.3 & & \\
\hline DG $03-278$ & DG $97-836 \times$ DG $97-886$ & 6.8 & 56.3 & 0.4 & 6.8 & 0.4 & 3.6 & & 3.6 & & 2.4 & 1.5 & 25 \\
\hline DG 00-270 & DG 91-6×DG 94-1530 & 6.8 & 46.8 & & 21.0 & & 0.8 & 2.4 & 21.9 & 3.2 & 3.9 & & \\
\hline DG $03-85$ & DG $97-14 \times$ DG $97-1805$ & 6.7 & 70.8 & 0.8 & 6.8 & 0.8 & 2.4 & 1.2 & 11.8 & 2.4 & 3.0 & & \\
\hline DG 00-349 & DG D8330×DG 93-243 & 6.5 & 58.5 & 0.8 & 13.2 & 0.8 & 5.4 & 3.2 & 13.3 & 3.2 & 1.6 & & \\
\hline DG 03-242 & DG $97-836 \times$ DG $97-761$ & 6.4 & 56.3 & 0.4 & 6.8 & 0.4 & 3.6 & & 3.6 & & 2.4 & 1.5 & 25 \\
\hline DG 94-15 & DG $89-395 \times$ DG $90-402$ & 5.4 & 64.8 & 1.6 & 13.9 & 1.6 & 7.7 & 4.0 & 1.6 & 4.0 & 0.8 & & \\
\hline DG 06-348 & DG $01-144 \times$ DG $00-525$ & 5.1 & 56.4 & 0.8 & 17.0 & 0.8 & 3.6 & 2.0 & 13.3 & & 2.8 & 3.3 & \\
\hline DG 92-227 & DG 89-358×DG 88-596 & 5.0 & 67.2 & & 3.9 & & 6.2 & & 12.5 & & 4.0 & 6.2 & \\
\hline DG 06-345 & DG $01-144 \times$ DG $00-525$ & 4.2 & 56.4 & 0.8 & 17.0 & 0.8 & 3.6 & 2.0 & 13.3 & & 2.8 & 3.3 & \\
\hline DG 01-139 & DG 92-227×DG 91-234 & 4.0 & 52.4 & & 6.2 & & 3.0 & 0.8 & 28.1 & 1.6 & 4.8 & 3.1 & \\
\hline DG $01-3$ & DG 91-28×DG 91-234 & 3.9 & 54.5 & 0.8 & 7.8 & 0.8 & 1.5 & 1.6 & 25.8 & 3.2 & 4.0 & & \\
\hline DG 06-5 & DG 00-519×DW 96-1025 & 3.8 & 69.7 & 1.8 & 10.6 & 1.2 & 6.8 & 1.4 & 5.9 & 1.8 & 0.8 & & \\
\hline DG $00-525$ & DG 94-15×DG 94-186 & 3.7 & 58.5 & 0.8 & 26.1 & 0.8 & 5.6 & 2.4 & 0.8 & 2.4 & 2.6 & & \\
\hline DG 04-812 & DG $94-15 \times$ DG $97-761$ & 3.2 & 68.2 & 1.0 & 11.5 & 1.0 & 6.4 & 2.0 & 4.2 & 2.0 & 2.2 & 1.5 & \\
\hline DG 06-1081 & DW 96-1025×DG 00-1017 & 2.8 & 66.0 & 1.2 & 18.0 & 1.2 & 5.4 & 0.6 & 4.3 & 1.0 & 2.3 & & \\
\hline DG 06-1 & DG $00-519 \times$ DW 96-1025 & 1.8 & 69.7 & 1.8 & 10.6 & 1.2 & 6.8 & 1.4 & 5.9 & 1.8 & 0.8 & & \\
\hline
\end{tabular}

S. acaule (acl): MP.IH. 08

S. chacoense (chc): MPI.H.408, PK 133 (Wyszobórz, Poland), CPC 3731, CPC3785, GLKS 66.51/6/6, CPC 3787, GLKS 66.8/26/4, GKLS 60.30/2R

S. demissum (dms): MPI.H.408

S. gourlai ( $g r l)$ : INTA 7356

S. microdontum $(m c d)$ : PI 26557

S. phureja (phu): MPI.H.408, CCC 1.3, PI 225696.1, $380051 / 7$ (CIP)

S. verrucosum (ver): PI 195170, CPC 2644, PI 5256, PI 275256

S. yungasense (yun): GLKS 67.107/3R

S. stenotomum $\times$ S. phureja $($ stn $\times$ phu): $375186.3 / 48$ (CIP)

S. tuberosum (tbr): own hybrids of tetraploid stock and cultivars; USW42; haploids of dH Black and dH Gineke from IVP (Holland); haploids of tetraploid stocks from Germany

S. goniocalyx (gon): KW 84-27-2571Hettema- Zonen B.V., (Holland)

$14.6{ }^{\circ} \mathrm{C}$ and $13.5^{\circ} \mathrm{C}, 16.2{ }^{\circ} \mathrm{C}, 20.0^{\circ} \mathrm{C}, 18.5^{\circ} \mathrm{C}, 14.3^{\circ} \mathrm{C}$ in 2008 and 2009, respectively. Diploid clones were hand- harvested in September and stored up to a bruising test at 5 to $10{ }^{\circ} \mathrm{C}$ and $95 \%$ relative humidity. 
Table 2 Characteristics of diploid clones and standard cultivars: blackspot bruising, starch content and quality traits, resistance to pathogens, ability to produce $2 n$ gametes and leading traits. Diploid clones are ordered according to increasing susceptibility to bruising

\begin{tabular}{|c|c|c|c|c|c|c|c|c|}
\hline Clone & $\begin{array}{l}\text { Mean surface } \\
\text { of blackspot } \\
\text { bruises }^{\text {a }}\end{array}$ & $\mathrm{SD}(+/-)$ & $\begin{array}{l}\text { Starch } \\
\text { content } \\
(\%)^{b}\end{array}$ & $\mathrm{SD}(+/-)$ & Quality traits ${ }^{\mathrm{c}}$ & Resistance to pathogens ${ }^{\mathrm{d}}$ & $\begin{array}{l}\text { Ability to big } \\
\text { pollen grains } \\
\text { formation }^{\mathrm{e}}\end{array}$ & $\begin{array}{l}\text { Leading } \\
\text { trait }^{\mathrm{f}}\end{array}$ \\
\hline DG $03-170$ & 9.0 & 0.0 & 10.1 & 0.5 & T,ED,ACD & $\mathrm{L}, \mathrm{Y}, \mathrm{X}, \mathrm{Sy}$ & $+_{X}$ & A \\
\hline DG $03-232$ & 9.0 & 0.0 & 13.7 & 0.8 & T,ED,ACD & $\mathrm{Y}$ & $+_{X}$ & A \\
\hline DG $03-460$ & 9.0 & 0.0 & 8.8 & 0.0 & T,ED,ACD & Y,Sy & $+_{X}$ & A \\
\hline DG 97-1805 & 9.0 & 0.1 & 9.5 & 1.7 & $\mathrm{~T}, \mathrm{ED}, \mathrm{ACD}$ & $\mathrm{Y,Pca}(6), \mathrm{Sy}$ & $+_{\mathrm{X}}$ & A \\
\hline DG 03-131 & 8.8 & 0.2 & 11.5 & 1.1 & $\mathrm{~T}, \mathrm{ED}, \mathrm{ACD}$ & $\mathrm{X}$ & $+_{\mathrm{X}}$ & A \\
\hline DG 03-226 & 8.7 & 0.0 & 14.3 & 0.4 & T,ED,ACD & & $+_{\mathrm{X}}$ & $\mathrm{A}$ \\
\hline DW 96-667 & 8.6 & 0.6 & 16.2 & 1.2 & $\mathrm{CCh}$ & $\mathrm{L}, \mathrm{X}, \mathrm{Y}, \mathrm{M}, \mathrm{Phl}(7.9), \mathrm{Sy}$ & $+_{\mathrm{X}}$ & $\mathrm{C}$ \\
\hline DG 03-124 & 8.5 & 0.4 & 13.4 & 0.8 & T,ED,ACD & PLRV,Y,X & $+_{\mathrm{X}}$ & A \\
\hline DW 96-1025 & 8.3 & 0.2 & 18.0 & 1.9 & $\mathrm{CCh}$ & Y,M,Pca(6),Phl(7.4),Sy & $+_{\mathrm{X}}$ & $\mathrm{B}$ \\
\hline DG $00-481$ & 8.3 & 0.0 & 19.6 & 0.0 & & $\mathrm{M}, \operatorname{Pca}(7)$ & ${ }^{+}{ }_{X}$ & $\mathrm{E}$ \\
\hline DG $03-150$ & 8.2 & 0.3 & 14.5 & 0.8 & $\mathrm{~T}, \mathrm{ED}, \mathrm{ACD}$ & L,Y,M,Pca(5)Sy & $+_{\mathrm{X}}$ & A \\
\hline DG 97-943 & 7.8 & 1.1 & 16.5 & 1.1 & $\mathrm{CCh}$ & X, M,Pca(5),Phl(8.9),Pht(8.7),Sy & ${ }^{+}{ }_{X}$ & $\mathrm{~B}$ \\
\hline DG 01-144 & 7.4 & 0.5 & 16.3 & 0.1 & $\mathrm{CCh}, \mathrm{T}, \mathrm{ED}, \mathrm{ACD}$ & Y,Phl(8.9),Pht(8.9),Sy & $+_{X}$ & $\mathrm{C}$ \\
\hline DG 01-290 & 7.0 & 1.2 & 16.7 & 1.1 & $\mathrm{CCh}, \mathrm{T}, \mathrm{ED}, \mathrm{ACD}$ & Y,Phl(9),Pht(8.9),Sy & + & $\mathrm{C}$ \\
\hline DG 06-1072 & 6.9 & 1.3 & 22.4 & 1.1 & & & & $\mathrm{D}$ \\
\hline DG 03-278 & 6.8 & 0.3 & 13.2 & 1.4 & $\mathrm{CCh}$ & $\mathrm{Y}, \mathrm{X}$ & ${ }^{+} \mathrm{X}$ & $\mathrm{B}$ \\
\hline DG $00-270$ & 6.8 & 0.4 & 21.5 & 1.5 & & $\mathrm{~L}, \mathrm{Y}, \mathrm{Pca}(7), \mathrm{Phl}(6.5)$ & + & $\mathrm{E}$ \\
\hline DG $03-85$ & 6.7 & 2.5 & 13.3 & 0.3 & $\mathrm{~T}, \mathrm{ED}, \mathrm{ACD}$ & X,Sy & + & A \\
\hline DG 00-349 & 6.5 & 2.4 & 22.0 & 1.3 & & $\mathrm{~L}, \mathrm{Y}, \mathrm{Pca}(7), \mathrm{Phl}(6.2)$ & & $\mathrm{E}$ \\
\hline DG 03-242 & 6.4 & 3.4 & 14.3 & 1.9 & $\mathrm{CCh}$ & PLRV,Y,Sy & & $\mathrm{B}$ \\
\hline DG 94-15 & 5.4 & 2.3 & 24.7 & 0.0 & & $\mathrm{~L}, \mathrm{Y}, \mathrm{M}, \mathrm{S}, \mathrm{Pca}(7), \mathrm{Phl}(8) \mathrm{Pht}(7.8)$ & & $\mathrm{D}$ \\
\hline DG 06-348 & 5.1 & 1.9 & 25.1 & 1.8 & & Sy & & $\mathrm{D}$ \\
\hline DG 92-227 & 5.0 & 1.4 & 13.4 & 0.7 & & $\mathrm{~L}, \mathrm{X}, \mathrm{Y}, \mathrm{Phl}(9)$ & + & $\mathrm{C}$ \\
\hline DG 06-345 & 4.2 & 0.8 & 23.6 & 0.3 & & Sy & & $\mathrm{D}$ \\
\hline DG 01-139 & 4.0 & 0.3 & 16.2 & 1.0 & CCh,T,ED,ACD & $\operatorname{Phl}(9), \operatorname{Pht}(8.9), \mathrm{Sy}$ & + & $\mathrm{C}$ \\
\hline DG 01-3 & 3.9 & 1.3 & 15.3 & 0.2 & $\mathrm{CCh}, \mathrm{T}, \mathrm{ED}, \mathrm{ACD}$ & Y,Phl(8.3),Sy & $+_{\mathrm{X}}$ & $\mathrm{C}$ \\
\hline DG 06-5 & 3.8 & 1.3 & 24.5 & 0.4 & & $\mathrm{Pca}(7), \operatorname{Phl}(8.3), \operatorname{Pht}(8.7), \mathrm{Sy}$ & & $\mathrm{D}$ \\
\hline DG $00-525$ & 3.7 & 1.0 & 23.9 & 0.2 & & L,M,Y,Pca(5.5),Sy & & $\mathrm{D}$ \\
\hline DG $04-812$ & 3.2 & 0.8 & 25.4 & 1.8 & & $\mathrm{Y}, \mathrm{X}, \mathrm{Pca}(6), \mathrm{Sy}$ & & $\mathrm{D}$ \\
\hline DG 06-1081 & 2.8 & 0.4 & 21.6 & 1.4 & & $\operatorname{Pca}(6)$ & & $\mathrm{D}$ \\
\hline DG 06-1 & 1.8 & 0.4 & 27.9 & 0.7 & & $\operatorname{Pca}(6.7), \operatorname{Phl}(7.9), \operatorname{Pht}(8.6), \mathrm{Sy}$ & & $\mathrm{D}$ \\
\hline Vitara & 8.9 & 0.2 & 12.8 & 0.0 & $\mathrm{~T}, \mathrm{ED}, \mathrm{ACD}$ & $\mathrm{L}, \mathrm{Y}$ & & $\mathrm{TC}$ \\
\hline Hinga & 5.0 & 1.4 & 20.9 & 3.0 & & $\mathrm{Y,Phl}(7)$ & & $\mathrm{SC}$ \\
\hline
\end{tabular}

a evaluated in scale $1-9$, where $=80.1$ to $100 \%$ of tuber surface covered by bruises, $2=60.1$ to $80 \%, 3=40.1$ to $60 \%, 4=25.1$ to $40 \%, 5=15.1$ to $25 \%, 6=10.1$ to $15 \%, 7=5.1$ to $10 \%, 8=0.1$ to $5 \%, 9$ - lack of bruises, mean value of 2 - year evaluation. SD- standard deviation

${ }^{\mathrm{b}}$ mean value of two-year evaluation; SD - standard deviation

c $\mathrm{T}$ - taste scored $\geq 6$; evaluated in scale $1-9$, where $9=$ the best

ED - high level of resistance to enzymatic discoloration of tuber flesh (in scale 1-9, where 1 - dark, 9 - light, acceptable score $\geq 8$ )

ACD - resistance to after- cooking darkening (in scale $1-9$, acceptable score $\geq 8$ )

$\mathrm{CCh}$ - chip color after 4-5 months of cold storage $\left(4^{\circ} \mathrm{C}\right)$ scores in scale $1-9$, where 1 - dark, 9 - light, acceptable score $\geq 6$

${ }^{\text {d }}$ L, Y, X, M resistance to PLRV, PVY, PVX, PVM; Phl, Pht, Pca, Sy resistance to P. infestans in leaves, to $P$. infestans in tuber slices, to $P$. carotovorum spp. carotovorum; to $S$. endobioticum

(values in brackets are mean resistance in scale 1-9, where 1- the most susceptible, 9 - the most resistant)

$\mathrm{e}+-$ ability to form big pollen grains; $+\mathrm{x}-$ seed set in $4 x \times 2 x$ crosses

${ }^{\mathrm{f}}$ A - table use; B - chip processing use; C - resistance to late blight; D - high starch content; E - resistance to soft rot

$T C$ table cultivar, $S C$ starch cultivar 
Assessment of Blackspot Bruise Resistance

Experiment was conducted in mid - February in two consecutive years 2009 and 2010. To assess the susceptibility to blackspot bruising 20 undamaged, non-greening tubers with standardized weight, were selected for tests. Sample tubers were stored for 5 months at 5 to $10{ }^{\circ} \mathrm{C}$. Blackspot bruise susceptibility was evaluated according to Domański et al. (2007). Just before test tubers were incubated for $12 \mathrm{~h}$ at $11^{\circ} \mathrm{C}$. After that tubers were placed in hexagon playwood drum and rotated ten times to produce simulated bruising (Douches et al. 2003). Subsequently, samples of tubers were stored for $72 \mathrm{~h}$ at $20^{\circ} \mathrm{C}$. Two-person team estimated visually a degree of bruising. Mean surface of blackspot bruises was evaluated for each tuber separately in scale 1 to 9 , where $1=$ 80.1 to $100 \%$ of tuber surface covered by bruises, $2=60.1$ to $80 \%, 3=40.1$ to $60 \%, 4=25.1$ to $40 \%, 5=15.1$ to $25 \%$, $6=10.1$ to $15 \%, 7=5.1$ to $10 \%, 8=0.1$ to $5 \%, 9$ - lack of bruises. Evaluations were performed in two replications, in each 10 tubers were tested.

\section{Assessment of Starch Content}

Starch content was determined by underwater weight method. Starch content (\%) was estimated from ratio of tuber weight in air (g)/tuber weight in water (g) according Lunden (1956).

\section{Assessment of L-Tyrosine Content}

L-tyrosine content was evaluated in tuber tissue extracts from 26 diploid hybrids collected from field in 2010.

Sample Preparation For analysis, five undamaged tubers from each diploid clone were taken. After skin removal, a cylindrical sample of tissue (ca $10 \mathrm{~mm}$ ) from the stolon and bud ends was taken using cork borer. Samples were immediately frozen in liquid nitrogen, freeze-dried and grounded to powder. $0.5 \mathrm{~g}$ of sample was homogenized for $2 \mathrm{~min}$ at maximum speed in Ultra-Turrax homogenizer with $8 \mathrm{~mL}$ of mixture containing methanol and $0.5 \%$ orthophosphoric acid (1 : 1) with BHT (butylated hydroxytoluene; $1 \mathrm{mg}$ $\left.\mathrm{mL}^{-1}\right)$. The extracts were centrifuged at $4,500 \times \mathrm{g}$ for $25 \mathrm{~min}$ at $20{ }^{\circ} \mathrm{C}$ and $6 \mathrm{ml}$ of supernatant was filtered and evaporated to dryness in a vacuum evaporator. Samples were diluted in $1.5 \mathrm{~mL}$ mixture of methanol and $0.5 \%$ orthophosphoric acid (in ratio $1: 1$ ), filtered through a $25 \mathrm{~mm}, 0.2 \mu \mathrm{m}$ syringe filter and $20 \mu \mathrm{L}$ was injected for HPLC analysis. Each extract was injected in triplicate.

HPLC Analysis RP-HPLC was performed with LC Prominence HPLC system (Shimadzu, Japan) comprising a pump LC - 20 AD, a vacuum degasser (DGU - $20 \mathrm{~A}_{3}$ ), UV - VIS detector (SPD-20 A) and using autosampler (SIL 20
ACHT). L - tyrosine standard was HPLC - grade purity from Roth (Switzerland). Methanol, acetonitrile, water and orthophosphoric acid were of HPLC-grade purity (POCh, Poland). Separation was performed using Vertex C-18 column $(4.6 \times 250 \mathrm{~mm}, 5 \mu \mathrm{m}$ particle, Knauer $)$ at $40{ }^{\circ} \mathrm{C}$. The mobile phase consisted of a binary solvent - $0.5 \%$ orthophosphoric acid (solvent $\mathrm{A}$ ) and acetonirile (solvent $\mathrm{B}$ ) and gradient elution ( 0 to $2 \mathrm{~min}, 5 \% \mathrm{~B} ; 2$ to $5 \mathrm{~min}, 5$ to $10 \% \mathrm{~B} ; 5$ to $7 \mathrm{~min}, 10 \% \mathrm{~B} ; 7$ to $10 \mathrm{~min}, 10$ to $15 \% \mathrm{~B} ; 10$ to $13 \mathrm{~min}, 15$ to $20 \% \mathrm{~B} ; 13$ to $23 \mathrm{~min}, 20 \% \mathrm{~B} ; 23$ to $25 \mathrm{~min}, 20$ to $30 \% \mathrm{~B} ; 25$ to $28 \mathrm{~min}, 30 \% \mathrm{~B} ; 28$ to $30 \mathrm{~min}$, 30 to $50 \% \mathrm{~B} ; 30$ to $32 \mathrm{~min}, 50 \% \mathrm{~B} ; 32$ to $33 \mathrm{~min}, 50$ to $5 \%$ $\mathrm{B} ; 33$ to $35 \mathrm{~min}, 5 \% \mathrm{~B})$ were used. Detection was at $275 \mathrm{~nm}$. The flow rate was set to $1 \mathrm{~mL} \mathrm{~min}^{-1}$. The external standard method of calibration was used with curve prepared from 5 different concentrations of the standard solution. The standard stock solution of $\mathrm{L}$ - tyrosine $1 \mathrm{mg} \mathrm{mL}^{-1}$ was prepared in methanol. L - tyrosine peak was identified by a direct comparison of its retention time with the standard.

\section{Statistical Analyses}

Analysis of variance (ANOVA) was performed to assess the effects of genotype, year and their interaction on the results of the blackspot bruise resistance. Broad-sense heritability for diploid hybrids was estimated according following formula: $\mathrm{H}_{\mathrm{b}}=\delta^{2}{ }_{\mathrm{g}} / \delta^{2}{ }_{\mathrm{g}}+\delta^{2}{ }_{\mathrm{ge}}+\delta^{2}{ }_{\mathrm{e}}$ (where, $\delta^{2}{ }_{\mathrm{g}}=\mathrm{M} 1-\mathrm{M} 2 / \mathrm{L} ; \delta^{2}{ }_{\mathrm{ge}}=$ $\mathrm{M} 2-\delta_{\mathrm{e}}^{2} ; \mathrm{M} 1=$ mean square of genotype; $\mathrm{M} 2=$ mean square of interaction year $\times$ genotype; $\mathrm{L}=$ number of year) (Domański et al. 2007). Homogenous groups of genotypes according to mean blackspot bruise resistance were distinguished by the Tukey's test. The reproducibility of the tests between years and the relationships of blackspot bruise resistance with starch content and L - tyrosine content were evaluated by calculating linear Pearson's correlation coefficients. All calculations were performed using computer program STATISTCA for Windows (Soft, Inc., Tulsa, OK, U.S.A.).

\section{Results}

Among tested diploid interspecific hybrids originated from wild Solanum species and dihaploids of S. tuberosum, 11 forms were highly resistant to bruising, scored above 8 (Table 2). S. tuberosum, S. phureja and S. chacoense were predominant in pedigrees of majority of the tested clones in comparison to remaining species. Additionally, in two clones, high contribution of $S$. goniocalyx in pedigree was observed (Table 1). Prevailing theoretical contribution of $S$. tuberosum (range 46.8 - 74.1\%) was noted both in susceptible and resistant forms. The associations between blackspot bruise resistance and content of any of predominant species in assessed 31 diploid clones were not proved. 
Most clones resistant to bruising were also resistant to potato viruses, some were resistant to $S$. endobioticum, P. infestans or P. carotovorum (Table 2). All these resistant genotypes produced big pollen grains which effectively worked in $4 x \times 2 x$ crosses in other studies.

Majority of clones classified as table stocks were highly resistant to bruising (Table 2). In other groups of usefulness, only single forms were resistant to blackspot bruise. All clones with high starch content were very susceptible to bruising. Starch content of all diploid hybrids varied from very low $(8.8 \%)$ to very high $(26.4 \%)$. Starch content of highly resistant clones ranged from 8.8 to $22.9 \%$, while starch content of diploids susceptible to bruising varied between 15.3 and $26.4 \%$. Starch content of cv. Vitara was $12.8 \%$ and cv. Hinga $20.8 \%$. Correlation coefficient between blackspot bruise resistance and starch content for all diploid genotypes was significant and negative $r=-0.67$ $(p<0.05)$. All tested diploid clones produced good yield. Average tuber weight of tested clones was ca. $30 \mathrm{~g}$ and the average yield was about $500 \mathrm{~g} /$ hill.

Two-year mean values of blackspot bruise resistance of diploid clones ranged from 1.8 to 9 and covered the whole scale. Significant variability in blackspot bruising among tested genotypes was confirmed by Tuckey's test at $p<$ 0.05 (Fig. 1, Table 3). Cv. Vitara was estimated as highly resistant to bruising (grade 8.9) and cv. Hinga as moderately susceptible (grade 5.0). The mean blackspot bruise resistance of diploid hybrids was significantly correlated between 2 years and the correlation coefficient at $p<0.05$ was $r=0.73$. Generally, standard deviations of two-year mean values of bruise resistance (Table 2, Fig. 1) were lower for highly resistant and highly susceptible clones than for clones classified as intermediate.

Analysis of variance of diploid genotypes showed significant effect of genotype and year on blackspot bruising susceptibility (Table 4). Genotype had the largest influence on blackspot bruise formation, explaining $85.1 \%$ of variance. The effect of year was weak, but significant and explained $5.0 \%$ of variance. Interaction between genotype and year was significant and explained next $13.4 \%$ of variance. Broadsense heritability of blackspot bruise for diploid genotypes was estimated as moderately high $\mathrm{H}_{\mathrm{b}}=0.73$.

The endogenous amounts of tyrosine for 26 diploid clones varied between 0.23 and $0.77 \mathrm{mg}$ per $1 \mathrm{~g}$ dry weight. In tubers of resistant and susceptible clones both high and low content of substrate was observed. For tested 26 genotypes correlation coefficient between blackspot bruise resistance and tyrosine content was not significant $(r=0.33, p>0.05)$.

\section{Discussion}

Presented studies were the first effort to evaluate the blackspot bruise resistance variation of diploid interspecific

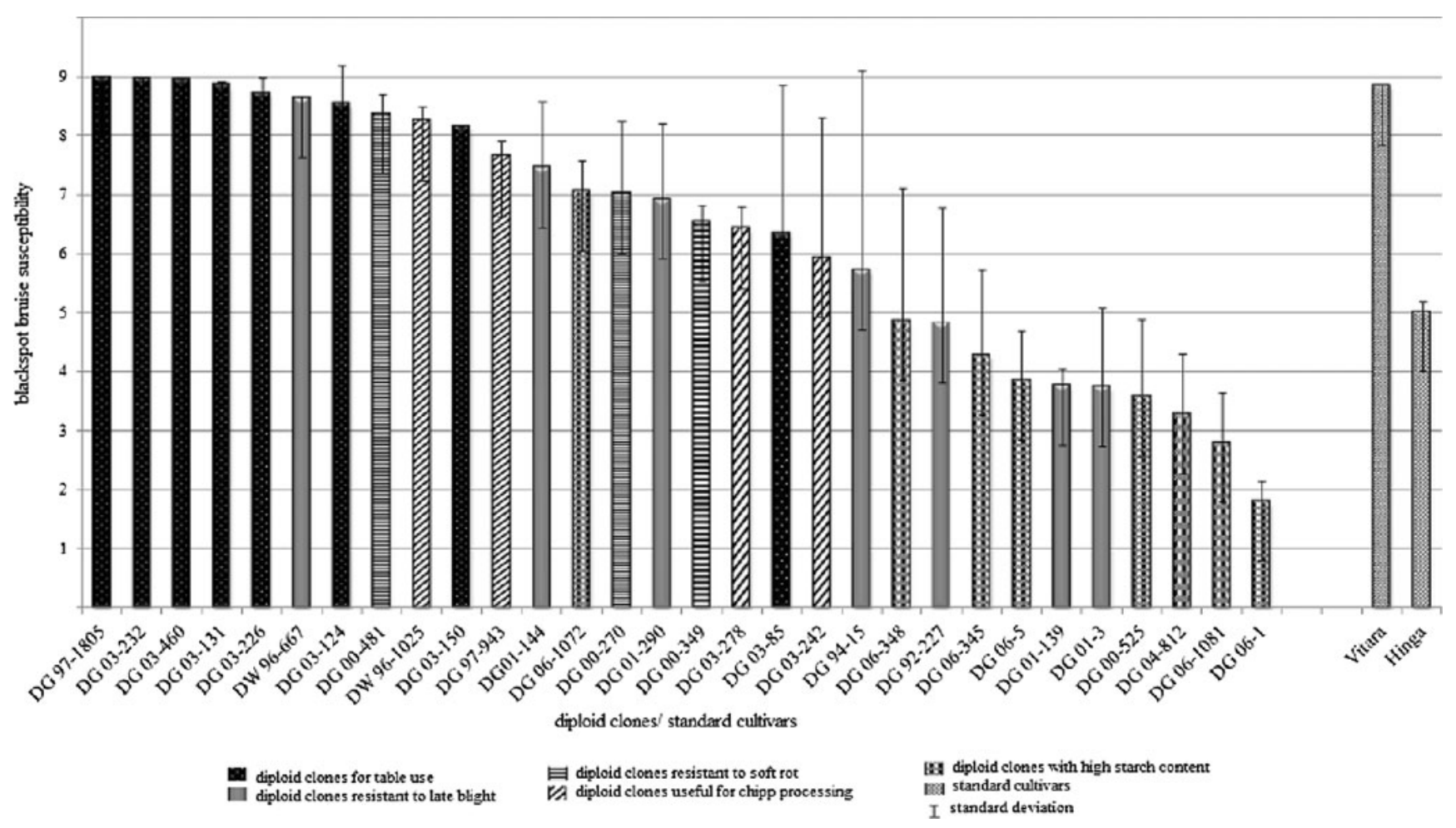

Fig. 1 Variability in blackspot bruise resistance among tested diploid potato clones with different leading traits and standard cultivars. Two-year mean values in $1-9$ scale, where $9=$ lack of bruises 
Table 3 Mean blackspot bruise susceptibility of 31 diploid genotypes and their classification according to Tukey's test at $p<0.05$

\begin{tabular}{|c|c|c|c|c|c|c|c|}
\hline \multirow[t]{2}{*}{ Diploid clones/standard cultivars } & \multicolumn{2}{|c|}{$\begin{array}{l}\text { Mean surface of } \\
\text { blackspot bruises } \\
\text { (range) }^{a}\end{array}$} & \multicolumn{5}{|c|}{$\begin{array}{l}\text { Homogenous groups according } \\
\text { to Tukey's test }\end{array}$} \\
\hline & $\min$ & $\max$ & & & & & \\
\hline DG 06-1 & 1.8 & & $\mathrm{a}$ & & & & \\
\hline DG 06-1081 & 2.8 & & $\mathrm{~b}$ & & & & \\
\hline DG $04-812$ & 3.2 & & & $\mathrm{c}$ & & & \\
\hline DG 00-525, DG 06-5, DG 01-3,DG 01-139 & 3.7 & 4.0 & & $\mathrm{c} d$ & & & \\
\hline DG $06-345$ & 4.2 & & & $\mathrm{~d} e$ & & & \\
\hline DG 92-227, cv. Hinga & 5.0 & & & & e $\mathrm{f}$ & & \\
\hline DG 06-348, DG 94-15 & 5.1 & 5.4 & & & $\mathrm{f}$ & & \\
\hline DG 03-242 & 6.4 & & & & $\mathrm{~g}$ & & \\
\hline DG 00-349, DG 03-85, DG 03-278, DG 00-270 & 6.5 & 6.8 & & & $\mathrm{~g}$ & $\mathrm{~h}$ & \\
\hline DG 06-1072, DG 01-290 & 6.9 & 7.0 & & & $\mathrm{~g}$ & $\mathrm{~h}$ i & \\
\hline DG $01-144$ & 7.4 & & & & & h i j & \\
\hline DG 97-943 & 7.8 & & & & & $\mathrm{i}$ j & $\mathrm{k}$ \\
\hline DG 03-150, DW 96-1025 & 8.2 & 8.3 & & & & $\mathrm{j}$ & $\mathrm{k} 1$ \\
\hline DG 00-481, DG 03-124, DW 96-667 & 8.4 & 8.7 & & & & & $\mathrm{k} 1$ \\
\hline DG 03-226, DG 03-131, DG 03-460, DG 03-232, DG 97-1805, DG 03-170, cv. Vitara & 8.8 & 9.0 & & & & & 1 \\
\hline
\end{tabular}

${ }^{\text {a }}$ scale $1-9$, where $9=$ lack of bruising

hybrids obtained in IHAR-PIB Młochów. Diploid clones used in our study have in their pedigree various Solanum species, like $S$. acaule, S. chacoense, S. demissum, S. goniocalyx, S. gourlayi, S. microdontum, S. phureja, $S$. verrucosum, S. yungasense and dihaploids of $S$. tuberosum. None of these species was documented before as a source of resistance to blackspot bruise or enzymatic blackening, a trait significantly correlated with bruising. 11 of tested clones were highly resistant to brusing and scored above 8, in 1-9 scale. Analyzing theoretical composition of species in pedigree of majority of tested clones $S$. tuberosum, $S$. phureja and $S$. chacoense were found as predominant species (Table 1). In highly resistant hybrids higher contribution of $S$. phureja in origin was observed in comparison to the most susceptible to blackspot bruise clones. Nonetheless, we cannot indicate which of species are exactly donors of resistance to blackspot bruise, because no relationship between blackspot bruise susceptibility and contribution of any predominant species was found (Table 1). Thus, we rather suspect that combination of specific alleles of genes determines decreasing discoloration formation after the impact. One of wild tetraploid 2 EBN species, S. hjertingii, has been recognized as a source of low enzymatic blackening (Woodwards and Jackson 1985). In this species the level of PPO was lower than in cultivated lines (Sim et al. 1997; Brown et al. 1999). There have been some attempts to transfer this trait to tetraploid level (Culley et al. 2002), however the use of sexual crosses of wild species directly to $S$. tuberosum, without prebreeding, means a laborious elimination of negative traits associated to the wild species. This option might be easier for selection when gene cloning and genetic engineering will be applied in breeding wider.

Tested diploid clones were obtained in long-term recombinant breeding process among above presented Solanum

Table 4 Analysis of variance for two-year mean values of blackspot bruise resistance for 31 diploid genotypes

\begin{tabular}{|c|c|c|c|c|c|c|c|}
\hline Factor & ${ }^{\mathrm{a}} \mathrm{Df}$ & ${ }^{\mathrm{b}} \mathrm{MS}$ effect & ${ }^{\mathrm{a}}$ Df error & ${ }^{\mathrm{b}}$ MS error & $F$ & ${ }^{c} R^{2}(\%)$ & $p$ \\
\hline$\{1\}$ Year & 1 & 3.1616 & 62 & 0.1103 & 28.6579 & 5.0 & 0.000001 \\
\hline$\{2\}$ Genotype & 30 & 18.9609 & 62 & 0.1103 & 171.8678 & 85.1 & 0.000000 \\
\hline $1 * 2$ & 30 & 2.9978 & 62 & 0.1103 & 27.1729 & 13.4 & 0.000000 \\
\hline
\end{tabular}

${ }^{\mathrm{a}}$ number of degrees of freedom

${ }^{b}$ mean standard effect/error

${ }^{c}$ percent of variance explained 
species (Table 1). In the years of selection most of wild features were eliminated. Previously these diploids were selected for quality and resistance traits (Jakuczun and Wasilewicz - Flis 2004). Effectiveness of function of $2 n$ pollen in $4 x \times 2 x$ crosses was also checked, and this character was frequent in tested set of diploids. In prior studies among tested diploid clones resistance to PLRV, PVX, PVY, PVM, $S$. endobioticum, $P$. infestans and $P$. carotovorum have been found (Table 2). High contribution of S. tuberosum in origin of tested hybrids determine good level of agronomic traits. Yield and average tuber weight of tested hybrids were on a good level, typical for interspecific hybrids selected for complex quality traits in IHAR - PIB Młochów.

Most of diploid clones highly resistant to bruising were useful for table use, and two of them were cold chippers (Table 2). It should be mentioned that some of presented clones have been successfully used as a source of "cold chipping" in $4 x \times 2 x$ crosses (Domański et al. 2006a, b, 2010). Authors have selected tetraploid progeny meeting desired agronomic and chipping quality traits on a better level than tetraploids obtained in traditional $4 x \times 4 x$ crosses.

The results of our studies indicated that blackspot bruise resistance was mainly influenced by genotype (85.1\%). Broadsense heritability of bruising potential was estimated as moderately high $\left(\mathrm{H}_{\mathrm{b}}=0.73\right)$. These results and conclusions from other studies (Pavek et al. 1993; Zgórska 2000; Komorowska-Jędrys et al. 2002; Domkáŕová and Vokál 2005; Domański et al. 2007; Urbany et al. 2011) have showed that the breeding for resistance to blackspot bruising could be very effective. Domański and coworkers (2007) from among 41 tested cultivars have identified several ones resistant to blackspot bruising. Authors have recommended them as source of this trait for potato breeding. Genetic pool of breeding potato needs new alleles of genes for broadening still narrowed variability. Thus, besides of cultivars the presented diploids could be the good donors of resistance to bruising. Diploid potatoes obtained in IHAR-PIB Młochów have been verified as good sources of other traits in $4 x \times 2 x$ program, like resistance to $P$. infestans (Śliwka et al. 2010), resistance to Pectobacterium spp. (Lebecka et al. 2004), cold chipping (Domański et al. 2006a, b), starch content and table traits (Domański et al. 2000, 2010).

It was found that a low level of tyrosine, the main substrate of discoloration reaction, is not related to resistance found in our diploid hybrids. The observed lack of correlation between low tyrosine content and resistance to bruising indicated that substrate level does not seem to be preliminary factor playing a main role in mechanism of bruising formation. This conclusion is in agreement with results of other studies (Mondy and Munshi 1993; Stevens and Davelaar 1997; Strehmel et al. 2010).

In this study we presented a chosen group of diploid potato hybrids and their value as potential donors of resistance to blackspot bruising. Although this trait is not the main one in selection processing, but taking into consideration fact, that bruising is responsible for significant decreasing of tuber yield, it is worth to intensify introducing of this trait to breeding material. Diploid potato hybrids are excellent materials for clarification of genetic background of resistance to bruising, which has not been still explained.

Acknowledgments We gratefully thank Ewa Zimnoch-Guzowska and Jadwiga Śliwka for their comments helpful in preparing of the manuscript.

Open Access This article is distributed under the terms of the Creative Commons Attribution License which permits any use, distribution, and reproduction in any medium, provided the original author(s) and the source are credited.

\section{References}

Arican, E., and N. Gozukirmizi. 2003. Reduced polyphenol oxidase activity in transgenic potato plants associated with reduced wound- inducible browning phenotypes. Biotechnology and Biotechnological Equipment 17(2): 15-21.

Brown, C.R., M. McNabnay, and B. Dean. 1999. Genetic characterization of reduced melanin formation in tuber tissue of Solanum hjertingii and hybrids with cultivated diploids. American Journal of Potato Research 76: 37-43.

Cobb, A.H. 1999. A review of the physiology of bruising in potatoes. The 14th Triennial Conference of the European Association for Potato Research, Sorrento, Italy: 198-199.

Coetzer, C., D. Corsini, S. Love, J. Pavek, and N. Tumer. 2001. Control of enzymatic browning in potato (Solanum tuberosum L.) by sense and antisense RNA from tomato polyphenol oxidase. Journal of Agricultural and Food Chemistry 49: 652-657.

Culley, D.E., B.B. Dean, and C.R. Brown. 2002. Introgression of the low browning trait from the wild Mexican species Solanum hjertingii into cultivated potato (S. tuberosum L.). Euthytica 125: 293-303.

Dean, B.B., N. Jackowiak, M. Nagle, J. Pavek, and D. Corsini. 1993. Blackspot pigment development of resistant and susceptible Solanum tuberosum L. genotypes at harvest and during storage measured by three methods of evaluation. American Potato Journal 70: 201-217.

Domański, L., M. Domańska, and H. Jakuczun. 2000. Evaluation of potato progenies and clones obtained from interploid crosses. Biuletyn IHAR 216: 497-503.

Domański, L., E. Zimnoch - Guzowska, M. Domańska, and H. Jakuczun. 2006a. The effect of hetreosis of diploid potato clone DG 97-943 of cold chipping type and producing $2 n$ gametes. Biuletyn IHAR 240(241): 307-313.

Domański, L., H. Jakuczun, and E. Zimnoch - Guzowska. 2006 b. Suitability of two diploid potato parental forms to developing the "cold chipping" tetraploid progenies. Zeszyty Problemowe Postępów Nauk Rolniczych 511: 115-121.

Domański, L., K. Michalak, and E. Zimnoch - Guzowska. 2007. Variation of blackspot susceptibility of the selected potato cultivars. Biuletyn IHAR 246: 145-149.

Domański, L., B. Flis, H. Jakuczun, and E. Zimnoch - Guzowska. 2010. Variation of processing quality and tuber morphology traits in potato progenies derived from interploid matings $4 x-2 x$. Biuletyn IHAR 257-258: 57-69.

Domkářová, J., and B. Vokál. 2005. The evaluation method of potato genotype resistance to blackspot bruise. Plant Soil and Environment 51(2): 74-81. 
Douches, D.D., R.W. Chase, J. Coombs, K. Flecher, L. Frank, J. Driscoll, E. Estellee, R. Hammerschmidt, and W. Kirk. 2003. Seventy-second annual report by Michigan State UniversityIn: National Germplasm Evaluation and Enhancement Report, 2001. Ed. By K.G. Haynes. Seventy Second Annual Report by Cooperators. US Departament of Agriculture, Agricultural Research Service, ARS-162: 171-199.

Jakuczun, H., and I. Wasilewicz - Flis. 2004. New sources of potato resistance to Phytophthora infestans at diploid level. Plant Breeding and Seed Science 50: 137-145.

Komorowska - Jędrys, J., T. Ohanowicz, and B. Szewczyk. 2002. Evaluation of potato tubers to after- wounding blackspot. Biuletyn IHAR 221: 147-152.

Lærke, P.E., E.R. Brierley, and A.H. Cobb. 2000. Impact - induced blackspots and membrane deterioration in potato (Solanum tuberosum L.) tubers. Journal of the Science of Food and Agriculture 80: 1332-1338.

Lærke, P.E., J. Christiansen, M.N. Andersen, and B. Veierskov. 2002a. Blackspot bruise susceptibility of potato tubers during growth and storage determined by two different test methods. Potato Research 45: 187-202.

Lærke, P.E., J. Christiansen, and B. Veierskov. 2002b. Colour of blackspot bruises in potato tubers during growth and storage compared to their discoloration potential. Postharvest Biology and Technology 26: 99-111.

Lebecka, R., E. Zimnoch - Guzowska, and Z. Kaczmarek. 2004. Resistance to soft rot (Erwinia carotovora subsp. atroseptica) in tetraploid potato families obtained from $4 x-2 x$ crosses. American Journal of Potato Research 82: 203-210.

Lunden, A.P. 1956. Underldokerd over forholdet mellom popetenes spesifikka vekt og deres torvstoff og Stivelsesinhold Forlh. Forso K Landbruket 7: 81-107.

McGarry, A., C.C. Hole, R.L.K. Drew, and N. Parsons. 1996. Internal damage in potato tubers: a critical review. Postharvest Biology and Technology 8: 239-258.

Mondy, N.I., and C.B. Munshi. 1993. Effect of maturity and storage on ascorbic acid and tyrosine concentrations and enzymatic discoloration of potatoes. Journal of Agricultural and Food Chemistry 41: $1868-1871$

Pavek, J., C.R. Brown, M.W. Martin, and D.L. Corsini. 1993. Inheritance of blackspot bruise resistance in potato. American Potato Journal 70: 43-48.
Peters, R. 1996. Damage of potato tubers, a review. Potato Research 39: 479-484.

Sim, S.K., S.M. Ohmann, and C.B.S. Tong. 1997. Comparison of polyphenol oxidase in tubers of Solanum tuberosum and the non browning tubers of $S$. hjeringii. American Potato Journal 74: 1-13.

Śliwka, J., H. Jakuczun, P. Kamiński, and E. Zimnoch-Guzowska. 2010. Marker-assisted selection of diploid and tetraploid potatoes carrying Rpi-phu1, a major gene for resistance to Phytophthora infestans. Journal of Applied Genetics 51(2): 133-140.

Stevens, L.H., and E. Davelaar. 1997. Biochemical potential of potato tubers to synthesize blackspot pigments in relation to their actual blackspot susceptibility. Journal of Agricultural and Food Chemistry 45: 4221-4226.

Storey, R. M .J. 2007. The harvested crop. In: Potato Biology and Biotechnology: Advances and Perspectives, ed. Vreugdenhil D. et al.: 459-468. Amsterdam, The Netherlands: Elsevier.

Strehmel, N., U. Praeger, C. Konig, I. Fehrle, A. Erban, M. Geyer, J. Kopka, and J.T. van Dongen. 2010. Time course effects on primary metabolism of potato (Solanum tuberosum L.) tuber tissue after mechanical impact. Postharvest Biology and Technology 56: 109-116.

Urbany, C., B. Stich, L. Schmidt, L. Simon, H. Berding, H. Junghans, K.-H. Niehoff, A. Braun, T. Eckhard, H.-R. Hofferbert, J. Lübeck, J. Strahwald, and C. Gebhardt. 2011. Association genetics in Solanum tuberosum provides new insights into potato tuber bruising and enzymatic tissue discoloration. BMC Genomics 12: 7.

Urbany, C., T. Colby, B. Stich, L. Schmidt, J. Schmidt, and C. Gebhardt. 2012. Analysis of natural variation of the potato tuber proteome reveals novel candidate genes for tuber bruising. Journal of Proteome Research 11(2): 703-716.

Woodwards, L., and M.T. Jackson. 1985. The lack of enzymic browning in wild potato species, Series Longipedicellata, and their crossability with Solanum tuberosum. Zeitschrift für Pflanzenzüchtung 94: 278-287.

Zgórska, K. 2000. Factors affecting the susceptibility of potato tubers to after- wounding blackspot. Biuletyn IHAR 213: 254-259.

Zimnoch-Guzowska, E., M.T. Sieczka, and K.M. Świeżyński. 1998. Development of parental lines for breeding potatoes resistant to viruses. p. 217-224. In Proceedings of the International Symposium: Breeding Research on Potatoes. 